\title{
Effect of different agro-waste substrates and their combinations on the yield and biological efficiency of Pleurotus sajor- caju
}

\author{
Poonam Dehariya and Deepak Vyas \\ Lab of Microbial technology and Plant Pathology \\ Department of Botany, Dr.H.S. Gour, University, Sagar (M.P.)
}

\begin{abstract}
Pleurotus sajor-caju Singer (Fr.) was cultivated on different agro-wastes viz. soybean straw, wheat straw, paddy straw, sugarcane bagasses, sun flower stalks, maize stalks, domestic waste, used tea leaves, fruit waste, semal flowers, news paper, bamboo leaves, saw dust and their combinations in 1:1 proportion to determine the effect of these agro waste on yield, growth and biological efficiency. Soybean straw showed significantly highest yield (with 93.3\% B.E.). Semal flowers required lesser time for spawn run (14.33 days) and pin head appearance (18.33 days). Among all the combinations soybean straw + wheat straw showed significantly highest yield (with $87.3 \%$ B.E.) and soybean straw + saw dust showed significantly lesser yield (with 43.8\% B.E.). Except Saw dust and News paper other test substrates were found suitable for the growth of Pleurotus sajor-caju.
\end{abstract}

Key words: Waste, Agro-wastes, straw, biological efficiency.

\section{Introduction:}

Oyster mushroom (i.e. Pleurotus spp.) is commonly called as Dhingri in India because of its oyster like shape. Genus Pleurotus belongs to family Tricholomataceae and has about 40 well-recognized species, out of which 12 species are cultivated in different parts of country. Pleurotus is an efficient lignin- degrading mushroom and can grow well on different types of lignocellulolosic materials. Cultivation of this Mushroom is very simple and low cost production technology, which gives consistent growth with high biological efficiency. Different species of Pleurotus can grow well in variable temperature conditions; hence they are ideally suited for cultivation throughout the year in various regions of tropical country like India (Ahmed et al.,2009). For many reasons the fungi of the Pleurotus genus have been intensively studied in many different parts of the world; they have high gastronomic value. They are able to colonize and degrade a large variety of lignocellulosic residues, they require shorter growth time when compared to other edible mushrooms, they demand few environmental controls, their fruiting bodies are not very often attacked by diseases and pests and they can be cultivated in a simple and cheap way (Patrabansh and Madan, 1997).

An attractive feature of oyster mushrooms is that they can utilize a large variety of agricultural waste products and transform the lignocelluloses biomass in to high quality food, flavor and nutritive value (Quimio, 1978; Bano and Rajarathanam, 1982; Jain and Vyas, 2003). Oyster mushroom posses the appropriate enzymatic mechanism for the transformation of complex organic macromolecules into simple compounds have been exploited as the means for biodegradation of a wide range of plant litter due to their particular ability for selective delignification (Mayson \& Verachtert, 1991; Martinez et al., 1994). Most agricultural residues are rich in lignocelluloses compounds whose handling and disposal often problematic. Wheat straw, Soybean straw, Paddy straw and Sugarcane bagasses are the substrates of interest, Since they are produced in large quantities and rich in cellulose and lignin. The potential of bioconversion of lignocelluloses waste into value added products is emphasized in earlier studies (Philippoussis \& Zervakis 2000; Poppe, 2000). The large amount of agricultural wastes and congenial climatic conditions provide tremendous scope for oyster mushroom cultivation in Sagar, M.P. (Vyas et al, 2009). In this study we took various conventional substrates viz. soybean straw (SS), wheat straw (WS), paddy straw (PS), Sun flower stalks (SFS), Sugarcane bagasses (SB), Maize stalks (MS) and non-conventional substrates viz. domestic wastes (DW), Fruit waste (FW), used tea leaves (UTL), Semal flowers (SF), news paper waste (NPW), Bamboo leaves (BL), Saw dust (SD) for the cultivation of Pleurotus sajor-caju.

\section{Materials and Methods:}

Spawn preparation: Clean whole grains were taken for the purpose. The grains were pre-wetted by boiling in water for 20-30 min (Jain, 2005). After boiling, excess water was drained off by spreading the grains on a wire mesh. Grains were now mixed with gypsum (calcium sulphate) and chalk powder (calcium carbonate) at the rate of $2 \%$ and $0.5 \%$, respectively on dry weight basis. The grains were filled in flasks, and plugged then sterilized in autoclave at $22 \mathrm{Lb}$ pressure for 1.5-2 hours. The grains were allowed to cool in room temperature for overnight. Next day flasks were inoculated with two bits of agar medium colonized with the mycelium of pure cultures. 
About 7-10 days after inoculation, flasks were shaken vigorously. Three weeks after incubation, the stock culture becomes ready for further multiplication of spawn. Inoculated flasks were incubated at $26 \pm 2^{\circ} \mathrm{C}$.

Cultivation: A medium was prepared using conventional viz. soybean straw (SS), wheat straw (WS), paddy straw (PS), Sun flower stalks (SFS), Sugarcane bagasses (SB), Maize stalks (MS)and non-conventional substrates viz. domestic wastes (DW), Fruit waste (FW), used tea leaves (UTL), Semal flowers (SF), news paper waste (NPW), Bamboo leaves (BL), Saw dust (SD). All substrates were washed in fresh water. The chopped straw substrates were steeped in water containing $75 \mathrm{ppm}$ bavistin $+500 \mathrm{ppm}$ formaldehyde for 18 hours (Jain, 2005) for preventing mould infestation due to various other competiting fungi. Supplements were sterilized with $25 \mathrm{ppm}$ bavistin for 12-18 hrs. Excess water was drained and was dried in shed to retain $65-70 \%$ moisture content by squeezing with hands and then allowed to cool down for a certain period (1hr.). Spawning was done @ $2 \%$ wet weight basis of substrate by thoroughly mixing. Spawned substrate was filled up in perforated polythene bags $(60 \times 40 \mathrm{~cm})$ and polythene mouth was closed with rubber band. These bags were transferred to crop room for spawn run. Three replications were maintained for each substrate. For spawn run, temperature and relative humidity were maintained between $25-30^{\circ} \mathrm{C}$ and $65-90 \%$, respectively. Polythene bags were cut open when the mycelial run was completed. The substrate beds were moistened by sprinkling of water thrice a day which was stopped a day before harvesting. Average values of observation with respect to duration of spawn run, time taken for first harvest yield and total yield was recorded. Biological efficiency of mushroom on fresh weight basis was calculated by using formula given by Chang and Miles (1989).

$$
\text { Biological efficiency }(\%)=\frac{\text { Yield of fruiting body }(\mathrm{gm})}{\text { Total weight of substrate used }(\mathrm{gm})}
$$

\section{Results:}

In present study six substrates generally regarded as conventional are used viz. soybean straw (SS), wheat straw (WS), paddy straw (PS), sugarcane bagasses (SB), sun flower stalks (SFS), maize stalks (MS) and non conventional are used viz. Domestic waste (DW), used tea leaves (UTL), fruit waste (FW), semal flowers (SF), news paper (NP), bamboo leaves (BL), saw dust (SD), for cultivation of $P$. sajor-caju. Table 1 shows that among these conventional substrates, SS was found best because of greater yield and BE was 933.4 gm and 93.3\%. Early spawn run (17.6 days) and pin head appearance (22.33 days), stipe length $(2.8 \mathrm{~cm})$, cap diameter $(7.8 \mathrm{~cm})$ found. Besides SS, WS $\left(800.0 \mathrm{~g} \mathrm{~kg}^{-1}\right)$ and PS $\left(743.4 \mathrm{~g} \mathrm{~kg}^{-1}\right)$ were found good substrates in terms of yield of mushroom. MS was found poor substrate in comparison to other conventional substrate because here yield was $530 \mathrm{~g} \mathrm{~kg}^{-1}$ was obtained. Though SB required comparatively more time for spawn run (26.6 days) and pin head appearance (32 days) yet yield was good (641.66 $\left.\mathrm{g} \mathrm{kg}^{-1}\right)$. However, all the substrates was found suitable for cultivation of Pleurotus sajor - caju.

As it is clearly evident from the data presented in the table 2 that among the non- conventional test substrate, BL required lesser time for spawn run (17 days) and pin head appearance (21.4 days) but average yield $\left(521.7 \mathrm{~g} \mathrm{~kg}^{-1}\right)$ was obtained. On the other hand DW was found to be best substrate because of higher yield (718.4 $\left.\mathrm{g} \mathrm{kg}^{-1}\right)$ and BE $(71.8 \%)$ obtained. Besides DW, UTL produces good yield $\left(655.0 \mathrm{~g} \mathrm{~kg}^{-1}\right)$. SD was found unsuitable and poor substrate because it not only require more time for spawn run (31.7 days) and pin head appearance (34.7 days) but also produces lowest yield $\left(321.7 \mathrm{~g} \mathrm{~kg}^{-1}\right)$ with $32.1 \% \mathrm{BE}$. In NP also more time (30.7 days) for spawn run and pin head appearance (34.7 days) was observed, but maximum stipe length (2.7) $\mathrm{cm}$ and cap diameter $(6.2) \mathrm{cm}$ measured with $558.4 \mathrm{~g} \mathrm{~kg}^{-1}$ yield and 55.8\% BE. Except SD and NP other test non conventional substrates were found suitable for the growth of Pleurotus sajor-caju.

Table 3 shows results of $P$. sajor- caju cultivated on different conventional substrates in combination with SS (w/w, 1:1). Among all the test substrate combinations, SS+WS produces maximum yield $\left(873.33 \mathrm{~g} \mathrm{~kg}^{-}\right.$ ${ }^{1}$ ) and required 17 days for spawn run, 21 days for pin head appearance, stipe length measured $3.1 \mathrm{~cm}$. and cap diameter $(8.06 \mathrm{~cm})$. Besides SS+WS combination, SS+PS was also found good substrate in terms of yield and other growth parameter. SS+MS combination was found comparatively less suitable combination because not only lesser yield was obtained but also spawn run time and pin head appearance took maximum time.

Table 4 shows growth and yield of $P$. sajor- caju on different non conventional substrates in combination with SS (w/w, 1:1). Among all the test combinations, SS+DW combination was showed best results therefore higher yield viz. $826.7 \mathrm{~g} \mathrm{~kg}-1$ with $82.6 \% \mathrm{BE}$ was recorded. 22 days for spawn run, 26.0 days for pin head appearance are required which are minimum among the test combinations. Stipe length $(3.2 \mathrm{~cm})$, cap diameter $(6.6 \mathrm{~cm})$ measured. SS+BL combination showed 12 days for spawn run and 16 days for pin head appearance and stipe length measured $2.7 \mathrm{~cm}$. and cap diameter was $(6.2 \mathrm{~cm})$ measured and yield recorded $570 \mathrm{~g}$ $\mathrm{kg}-1$ with $57.0 \%$ BE. SS + SD was found unsuitable substrate because it required more time (29 days) for spawn run and (33.4 days) for pin head appearance. Though, stipe length $(2.8 \mathrm{~cm})$ and cap diameter $(6.9 \mathrm{~cm})$ were measured are good yet yield was obtained lesser $\left(438.33 \mathrm{~g} \mathrm{~kg}^{-1}\right.$ with $\left.43.8 \% \mathrm{BE}\right)$. 


\section{Discussion:}

Among various species of mushrooms, cultivation of Pleurotus spp is picking very fast due to its easy cultivation technology, adaptability to wide range of temperature and ability to grow on a variety of lignocellulosic substrates (Gogoi and Adhikary, 2002). According to Singh et al., (2007) Pleurotus sp. through their extracellular enzyme degrades vegetable waste utilize the substrate for growth. Pleurotus sajor- caju was found to utilize all the agricultural wastes and were observed suitable for spawn run, yield and biological efficiency (Das et al., 2000). In recent past many workers have reported cultivation of Pleurotus species on various substrates. Kumar et al., 2004, Chandra et al., 1998 reported the successful cultivation of Pleurotus sp. on conventional substrates. Jain and Vyas, 2005 reported Soybean and paddy straw found good for the cultivation of Pleurotus. Sangeetha and Theradimani (2007), Bano and Shrivastava, (1962); Jandaik and Kapoor (1974); Khanna and Garcha (1982) reported paddy straw are better substrate for Pleurotus cultivation. Sharma and Jandaik (1981) reported that P. sajor-caju cultivation on wheat straw took 32 days for the first harvest. Pleurotus has also been reported to grow readily on a number of non- conventional substrates (Das et al., 2000; Mukherjee and Nandi, 2002; Shah et al., 2004; Nageshwaran et al., 2003;). Used tea leaves was used for production of Pleurotus sajor-caju with low biological efficiency in India (Pani et al., 1997).

Mushroom cultivation on waste paper was recorded by Baysal and Paker in 2001.Yamashita et al., (1983) reported cultivation of Pleurotus sajor caju on lawn grass. Ingale and Ramteke (2010) reported cultivation and biological efficiency of mushrooms grown on different agro-residues Mane et al., (2007) grew $P$. sajor caju in several agro-industrial residues: cotton processing residue, wheat straw, soy straw, pea stalk and peanut stalk. Pandey et al., (2008) reported performance of oyster mushroom ( $P$. sajor-caju) on different agricultural wastes. The lower performance and yield of different agricultural wastes might be due to low lignolytic and cellulytic activity (Pathak and Goel, 1988). However high and significant performance of other substrates ensures the possibilities of utilizing the locally available substrates for Pleurotus sajorcaju cultivation.

\section{References:}

[1]. Ahmad, S.A., Kadam, J.A., Mane, V.P., Patil, S.S. and Baig, M.M.V. (2009) Biological efficiency and nutritional contents of Pleurotus florida cultivated on different agro-wastes. Nature and Sceince. 7: 44-48.

[2]. Bano, Z. and Rajarathanam, S. (1982). Studies on the cultivation of Pleurotus sajor-caju, The Mushroom Journal. 115: 243-245.

[3]. Bano Z, and Srivastava H.C. (1962). Studies in the cultivation of Pleurotus sp. on paddy straw. Food Sci.: 12: 363-368

[4]. Baysal, E. and Packer, H. (2001). An alternate to waste paper recycling; Mushroom cultivation. Technology, Sayi, 3-4: 9-13.

[5]. Chandra, S., Singh, A. K., Bhat, M.N. and Kumar, S., (1998). Yield performance of Pleurotus sajor-caju on some selected substrate in North- East region of India. Mushroom Research. 7, 2, 79-80.

[6]. Chang, S. T. and Miles, P. G. (1989). Edible Mushrooms and their Cultivation. CRC Press, Boca Raton.345.

[7]. Das, N., Mahapatra, S.C., and Chattopadhyaya, R.N., (2000). Use of wild grasses as substrate for cultivation of Oyster mushroom in south west Bengal. Mushroom Research. 9, 2: 95-99.

[8]. Gogoi, G. and Adhikary, A.K. (2002). Suitability of certain newer plant waste for production of oyster mushroom. Mushroom Res.II: $25-27$.

[9]. Ingale, A. and Ramteke, A. (2010). Studies on cultivation and biological efficiency of mushrooms grown on different agro-residues. Innovative Romanian food biotechnology.6: 25-28.

[10]. Jain, A.K. and Vyas, D. (2005). Comparative study on the yield of three Pleurotus sp. grown in several lignocelluloses Byproducts. J. Basic Appl. Mycol. 4: 155-157.

[11]. Jain, A. K. and Vyas, D. (2003). Cultivation of three Pleurotus sp. on different substrates J. Basic Appl. Mycol. 2: 88-89.

[12]. Jandaik C.L., Kapoor JN. (1974). Studies on cultivation of Pleurotus sajor-caju (Fr.) Singer. Mush Sci. 9: 667-672.

[13]. Khanna P, Garcha HS.1982. Utilization of paddy straw for cultivation of Pleurotus species. Mush Newslett Trop.: 2(1):5-9

[14]. Kumar, M., Singh, P.N., Singh, M., and Chand, G. (2004). Evaluation of different substrates for production of Oyster mushroom (Pleurotus sajor- caju) on different agro substrates. Farm science journal. 13: 169.

[15]. Mane, V.P., Patil, S.S., Syed A.S. and Baig M.M.V. (2007). Bioconversion of low quality lignocelluloses agricultural waste into edible protein by Pleurotus sajor caju (Fr.) Singer. J. Zhejiang Univ. B. 8: 745-751.

[16]. Martinez, A.T., Camarero, S., Guillen, F., Gutierrez, A., Munoz, C. Varela, E., Martinez, M.J., Barrasa, J. M. ,Ruel, K. and Pelayo, M. (1994). Progress in biopulping of non- woody materials: Chemical, Enzymatic and ultrastructural aspect of wheat straw delignification with lignolytic fungi from the genus Pleurotus. FEMS Microbiology Reviews 13, $265-274$.

[17]. Mayson, E. and Verachert, H. (1991). Growth of higher fungi on wheat straw and their impact on the digestibility of the substrate. Applied Microbiology and Biotechnology 36, 421-424.

[18]. Mukherjee R, Nandi B. (2001). Changes in dry matter digestibility and composition of bioconverted mustard biomass by two Pleurotus sp. under mushroom growing conditions. J Sci Ind Res.: 60: 405-409

[19]. Nageshwaran, M, Gopalkrishnan, M., Ganeshan, Vedhamurthy, A. and Selaganapadhy, E. (2003). Evaluation of water hyacinth for culture of oyster mushrooms. J. Aqua Plant Manag 41:122-123.

[20]. Pandey, R. K., Pandey, I.B.P. and Jha, S. (2008). Performance of Oyster mushroom (P. sajor-caju) on different agricultural wastes. Agricultura- Stiinta si practica. 3-4: 67-68.

[21]. Pani, B., S. Panda, and S. Das. (1997). Utilization of some by-products and other wastes for sporophore production of oyster mushroom. Orissa Journal Horticulture 25: 36-39.

[22]. Patrabansh, S., and Madan, M. (1997). Studies on cultivation, biological efficiency and chemical analysis of Pleurotus sajor-caju (Fr.) Singer on different biowastes. Acta Biotechnologica. 17: 107-122.

[23]. Philippoussiis, A. and Zervakis, G. (2000). Management of agro-industrial wastes through the cultivation of edible mushrooms. Proceedings of the fourth waste Forum, Milano.

[24]. Poppe, J. (2000). Use of agricultural waste materials in the cultivation of mushrooms. In Proceedings of the 15 th International Congress on the Science and Cultivation of edible fungi, ed. Van Griensive L.J.L.D., 3-23. Rotterdam; Balkema. 
ISBN 90-5809-1449

[25]. Pathak, N.C. and Goel, R. (1988). Perspectives in Mycology and Plant pathology 103-122 Malhotra publishing house, New Delhi. India

[26]. Quimio, T. H. (1978). Introducing Pleurotus flabellatus for your dinner table Mushroom Journal, 69:282-283.

[27]. Sangeetha, A. and Theradimani, M. (2007). Evaluation of different plant waste for the cultivation of different plant wastes for the cultivation of Oyster Mushroom (Pleurotus citrinopileatus) Mushroom Research.16 (1): 9-11.

[28]. Sharma, A.D. and Jaindaik, C.L. (1981). Yield potential and Economics of Pleurotus spp. Cultivation on Wheat straw Under Solon Conditions; Indian Mushroom Journal, 7,(1-2): 11

[29]. Shah, Z. A., Asar, M. and Ishtiaq. (2004). Comparative study on cultivation and yield performance of oyster mushroom on different substrates (wheat straw, leaves, saw dust). Pakistan J. Nutrition 3: 159-160.

[30]. Singh, S.K., Singh, D. and Rai, J.P.N. (2007). Evaluation of substrate suitability for oyster mushroom cultivation. Indian J. Ecol. 34: 88-89.

[31]. Vyas, D., Chaubey, A., Dehariya, P., Wagay, A. J., Bajpai, A. and Lodhwal, R. K. (2009). Mushroom Cultivation a Tool for Agri-preneurship and Rural Management, Perspectives on Agripreneurship and Rural Development, ICARD, International Conference on Agripreneurship \& Rural Development, BHU, Varanasi, India. 463-470.

[32]. Yamashita I, Mori T, Tino K, Yanai S. (1983). Utilization of cobs tears husk, peanut shell, lawn grass and porous stone for cultivation of oyster mushroom (Pleurotus ostreatus Jacqex. Fr.). Quat J Fd Sci Technol.: 30: 693-697.

Table: 1 Pleurotus sajor- caju cultivated on different conventional substrates.

\begin{tabular}{|l|c|c|c|c|c|c|}
\hline \multicolumn{1}{|c|}{ Substrates } & $\begin{array}{c}\text { Spawn } \\
\text { run } \\
\text { (days) }\end{array}$ & $\begin{array}{c}\text { Pin head } \\
\text { appearance } \\
\text { (days) }\end{array}$ & $\begin{array}{c}\text { Stipe } \\
\text { length } \\
\text { (cm.) }\end{array}$ & $\begin{array}{c}\text { Cap } \\
\text { diameter } \\
\text { (cm.) }\end{array}$ & $\begin{array}{c}\text { Total } \\
\text { harvest yield } \\
\text { (gm./Kg.) }\end{array}$ & $\begin{array}{c}\text { Biological } \\
\text { efficiency } \\
\text { (BE\%) }\end{array}$ \\
\hline Soybean straw & 17.6 & 22.33 & 2.8 & 7.8 & 933.4 & 93.3 \\
\hline Wheat straw & 19.0 & 23.33 & 2.7 & 8.1 & 800.0 & 80.0 \\
\hline Paddy straw & 21.33 & 25.33 & 2.8 & 8.0 & 743.4 & 74.3 \\
\hline Sun flower stalks & 20.66 & 24.33 & 2.5 & 6.9 & 655.0 & 65.5 \\
\hline Sugarcanebagasses & 26.66 & 32.0 & 2.9 & 6.4 & 641.7 & 64.1 \\
\hline Maize stalks & 20.0 & 26.0 & 2.6 & 6.9 & 530.0 & 53.0 \\
\hline S Em $( \pm)$ & 0.68 & 0.68 & 0.07 & 0.17 & 12.24 & 1.1 \\
\hline CD $(0.05 \%)$ & 2.09 & 2.09 & 0.22 & 0.53 & 37.73 & 3.7 \\
\hline
\end{tabular}

Table: 2 Pleurotus sajor caju cultivated on different non-conventional substrates.

\begin{tabular}{|c|c|c|c|c|c|c|}
\hline Substrates & $\begin{array}{c}\text { Spawn } \\
\text { run (days) }\end{array}$ & $\begin{array}{c}\text { Pin head } \\
\text { appearance } \\
\text { (days) }\end{array}$ & $\begin{array}{c}\text { Stipe } \\
\text { length } \\
\text { (cm.) }\end{array}$ & $\begin{array}{c}\text { Cap } \\
\text { diameter } \\
(\mathrm{cm} .)\end{array}$ & $\begin{array}{c}\text { Total } \\
\text { harvest yield } \\
\text { (gm./Kg.) }\end{array}$ & $\begin{array}{c}\begin{array}{c}\text { Biological } \\
\text { efficiency }\end{array} \\
(\mathrm{BE} \%) \\
\end{array}$ \\
\hline Domestic waste & 24.6 & 29 & 2.4 & 6.8 & 718.33 & 71.8 \\
\hline Fruit waste & 30.33 & 35.0 & 2.5 & 6.2 & 635.0 & 63.5 \\
\hline Used tea leaves & 25.6 & 31.66 & 2.3 & 5.6 & 655.0 & 65.5 \\
\hline Semal flowers & 14.33 & 18.33 & 3.46 & 4.8 & 623.4 & 62.3 \\
\hline News paper & 30.66 & 34.66 & 2.7 & 6.2 & 558.33 & 55.8 \\
\hline Bamboo leaves & 17.0 & 21.33 & 2.3 & 5.6 & 521.66 & 52.1 \\
\hline Saw dust & 31.66 & 35.0 & 2.5 & 5.2 & 321.66 & 32.1 \\
\hline $\mathrm{S} \operatorname{Em}( \pm)$ & 0.72 & 0.74 & 0.07 & 0.09 & 23.08 & 2.3 \\
\hline $\mathrm{CD}(0.05 \%)$ & 2.19 & 2.26 & 0.22 & 0.29 & 7.61 & 0.7 \\
\hline
\end{tabular}

Values are given in average of three replicates in both tables.

Table: 3 Pleurotus sajor- caju cultivated on different conventional substrates combination with Soybean straw.

\begin{tabular}{|c|c|c|c|c|c|c|}
\hline Substrates & $\begin{array}{c}\text { Spawn } \\
\text { run (days) }\end{array}$ & $\begin{array}{l}\text { Pin head } \\
\text { appearance } \\
\text { (days) }\end{array}$ & $\begin{array}{l}\text { Stipe } \\
\text { length } \\
\text { (cm.) }\end{array}$ & $\begin{array}{l}\text { Cap diameter } \\
(\mathbf{c m} .)\end{array}$ & $\begin{array}{l}\text { Total yield } \\
\text { (gm./Kg.) }\end{array}$ & $\begin{array}{c}\text { Biological } \\
\text { efficiency } \\
(\text { BE\%) }\end{array}$ \\
\hline SS control & 17.6 & 22.33 & 2.8 & 7.8 & 933.4 & 93.3 \\
\hline $\mathrm{SS}+\mathrm{WS}$ & 17.0 & 21.0 & 3.1 & 8.1 & 873.4 & 87.3 \\
\hline $\mathrm{SS}+\mathrm{PS}$ & 20.0 & 23.7 & 2.7 & 8.0 & 853.4 & 85.3 \\
\hline $\mathrm{SS}+\mathrm{SFS}$ & 21.7 & 26.7 & 2.6 & 6.8 & 700.0 & 70.0 \\
\hline $\mathrm{SS}+\mathrm{MS}$ & 24.0 & 29.4 & 2.7 & 7.1 & 621.7 & 62.1 \\
\hline $\mathrm{SEm}( \pm)$ & 0.78 & 0.83 & 0.06 & 0.06 & 10.58 & 0.6 \\
\hline $\mathrm{CD}(0.05 \%)$ & 2.40 & 2.58 & 0.20 & 0.20 & 32.61 & 2.1 \\
\hline
\end{tabular}


Effect of different agro-waste substrates and their combinations on the yield and biological efficiency

Table: 4 Pleurotus sajor- caju cultivated on different non-conventional substrates combination with Soybean straw

\begin{tabular}{|c|c|c|c|c|c|c|}
\hline Substrates & $\begin{array}{c}\text { Spawn } \\
\text { run (days) }\end{array}$ & $\begin{array}{l}\text { Pin head } \\
\text { appearance } \\
\text { (days) }\end{array}$ & $\begin{array}{l}\text { Stipe } \\
\text { length } \\
\text { (cm.) }\end{array}$ & $\begin{array}{c}\text { Cap } \\
\text { diameter } \\
(\mathbf{c m} .)\end{array}$ & $\begin{array}{c}\text { Total } \\
\text { harvest yield } \\
\text { (gm./Kg.) }\end{array}$ & $\begin{array}{c}\text { Biological } \\
\text { efficiency } \\
\text { (BE\%) }\end{array}$ \\
\hline SS control & 17.6 & 22.4 & 2.8 & 7.8 & 933.4 & 93.3 \\
\hline $\mathrm{SS}+\mathrm{DW}$ & 22.0 & 26.0 & 3.2 & 6.6 & 826.7 & 82.6 \\
\hline $\mathrm{SS}+\mathrm{UTL}$ & 23.83 & 28.0 & 2.5 & 6.1 & 730.0 & 73.0 \\
\hline $\mathrm{SS}+\mathrm{FW}$ & 28.33 & 33.0 & 2.8 & 6.0 & 728.4 & 72.8 \\
\hline $\mathrm{SS}+\mathrm{SF}$ & 15.4 & 19.4 & 3.6 & 5.5 & 691.7 & 69.1 \\
\hline $\mathrm{SS}+\mathrm{NP}$ & 27.33 & 32.4 & 3.0 & 6.7 & 583.3 & 58.3 \\
\hline $\mathrm{SS}+\mathrm{BL}$ & 12.0 & 16.0 & 2.7 & 6.2 & 570.0 & 57.0 \\
\hline $\mathrm{SS}+\mathrm{SD}$ & 29.0 & 33.4 & 2.8 & 6.9 & 438.4 & 43.8 \\
\hline $\mathrm{S} \operatorname{Em}( \pm)$ & 0.57 & 0.71 & 0.06 & 0.12 & 14.70 & 1.4 \\
\hline $\mathrm{CD}(0.05 \%)$ & 1.72 & 2.14 & 0.19 & 0.36 & 44.08 & 4.4 \\
\hline
\end{tabular}

Values are given in average of three replicates in both tables. 